\title{
Some aspects of Batswana traditional beliefs as reflected by an intertextual analysis of Mothoagae's poetry
}

\author{
D.S. Matjila \\ Department of African Languages, University of South Africa \\ P.O. Box 392, UNISA 0003, Pretoria, South Africa \\ matjids@unisa.ac.za
}

\begin{abstract}
In this article, the relationship between D.M. Mothoagae's poetry and that of other Batswana poets is analysed. Mothoagae's poetry is ingested with citations and echoes of and/or allusions to other Setswana poems. The study of relationships between texts is referred to as intertextuality.

The aim of this article is to demonstrate the relationship between some Setswana poems through an intertextual analysis and to determine the relationship between the written texts and cultural practices of the Batswana. In this study, use was made of J. Hillis Miller's theory of the host/parasite and parasite/ host relationship. This means that there is a mutual relationship between the texts. The parasite text borrows the image from the host text and the image borrowed from the host text gains more meaning and clarity from the parasite text.
\end{abstract}

\section{Introduction}

The intention of this article is to:

- comment briefly on work that has been done on poetry written in the vernacular and Setswana, in particular

- explain the origin and nature of intertextuality

- analyse Mothoagae's poetry using Miller's (in Bloom, 1979) theory of parasite/host and host/parasite; a reciprocal relationship.

Mothoagae is a prolific writer, but his works do not enjoy wide readership among the Batswana. According to a computer search, no study of his work has yet been done. It is the author's contention that a critical analysis of Mothoagae's works will heighten the reading public's appreciation of them and motivate them to evaluate other Setswana literary works.

\section{Review of existing literature}

It is important to examine briefly what previous scholars have done about poetry written in the vernacular because there are misconceptions and unfounded pronouncements about its contents and structure. For instance, French missionaries made the following unfounded remark about African traditional poetry:

In the eulogies, there is neither rhythm, meter nor rhyme, in other words, nothing that constitutes proper verse as we know it. (Kunene, 1970:xi)

However, other scholars such as Van Zyl (1941:8) maintain that praise poetry supplies an interesting study of the ability to observe the hard facts of life. He also notes that it arouses poetic feelings by, among others, inspiring fear in persons or objects and creating a sense of mystery and cruelty.

Moloto (1969:1) asserts that written Setswana poetry is of recent birth, but that the unwritten traditional lore dominates. The reader therefore has not only to reckon with previous studies in poetry in general, but with traditional lore as well that must be collected from bards who received it from previous generations and maintained it orally. It will be found to occupy quite a prominent place. English poetry also had humble beginnings. It was composed by humble people of humble calling, such as the poet and herdsman, Caedman, who received the power of song through visions. The same situation is depicted in Setswana traditional poetry, which is largely oral because of its historical back- 
ground. The poets come from all walks of life, from herdsmen to noblemen. Nonetheless, the most important feature of poetry is its language. There is a view which suggests that literature differs from 'practical' language because of its quintessential literary use of the language i.e. the artistic use of language is seen as a refined expression, constructed with a quality of its own. Peck and Coyle (1984:37-38) make this observation:

The difficulty is, however, that the term imagery covers not only these basic elements of presenting the situation but also the figurative use of language in poetry: 'figurative' means language being used in a non-literal way: most commonly the poet uses either a metaphor or a simile to extend the significance of what he is saying.

Poetic language differs from ordinary language. Ordinary language would, for example, speak of fortune and troubles, whereas the language of poetry would refer to them as slings and arrows. In this case, language is used figuratively to make the ideas vivid (Peck \& Coyle, 1984:139).

Today, there is irrefutable evidence that even modern compositions in the vernacular are indeed poetry. Imagery, hyperbole, parallelism, linking, comparison, repetition etc. are features of poetry written in the vernacular.

Moloto (1969:1) emphasizes the fact that the attitude expressed in African poetry is not just of approval but appraisal, not just of appreciation but depreciation, too. In this way, Moloto (1969) underlines the functionality of poetry written in the vernacular. Poetry also exists in other African languages. For example, according to Vilakazi (1938:116), the question of poetry in isiZulu is not whether or not it exists, but whether izibongo can be considered poetry. He continues:

Personally I contend that they are poetry, because in studying the language of their composition one does not fail to discover a deep and genuine imaginative tone. (Vilakazi, 1938:116)

Modern African poetry has developed from the oral tradition. Myths, legends and folktales are discernible modes of expression in African poetry. Up to now, most studies of poetry written in the vernacular have concentrated on aspects such as theme and artistic expression, for example, Lenake's (1984) artistic expression, Ntuli's (1984) artistic expression and Milubi's (1988) theme. Moleleki (1988), however, based his investigation on three aspects of K.P.D. Maphalla's poetry, namely, influence, imagery and protest. Influence constitutes one of the main poetic devices that give amplitude to the poet's compositions. Imagery is used as a window through which the reader catches a glimpse of the poet's mind.

Moleleki's (1988) study is a valuable contribution because it breaks new ground in the analysis of vernacular poetry. It shows that, while Sesotho poetry is functional in its thrust, it also preens itself with poetic aestheticism.

\section{Intertextuality}

The purpose of this article is to analyse the relationship between Mothoagae's poetry and that of other Batswana poets. Mothoagae's poetry, like any other poet's, is ingested with citations and echoes of and/or allusions to other Setswana poems. It is the author's viewpoint that this kind of connection does not imply an imitative relationship between the source and the influenced object. The study of relationships between texts is referred to as intertextuality.

Literary critics have different descriptions and interpretations of the concept intertextuality. According to its founder, Julia Kristeva, as reported in Plottel and Charney (1978:xiv), the word intertextuality has been coined from the French:

tout texte se construit comme mosaique de citations, tout texte est absorption et transformation d'un autre texte.

'Every text builds itself as a mosaic of quotations; every text is absorption and transformation of another text.' 
This means that when one has to interpret a text, one never arrives at the absolute answer. Each reading reveals a new facet, hitherto not perceived or hitherto not comprehended. The text undergoes changes. It is written within a particular semantic frame which, even as it is being generated, is already subjected to change, i.e. the text contributes to the whole corpus of meaning and this contribution may expand or delimit the meaning of the word, a phrase, a sentence or a sign.

Culler (1981:103) opines that intertextuality becomes less a name for a work's relation to particular prior texts than a designation of its participation in the discursive space of culture: the relationship between a text and the various languages or signifying practices of a culture and its relation to those texts which articulate for it the possibilities of that culture. According to Culler (1981), intertextuality therefore does not only illustrate the association between texts, but also points out the customs, artistic contributions and social institutions of a particular group or different groups of people, including their language. In other words, intertextuality addresses the way of writing, reveals unfilled gaps, and finally expresses the capabilities of a given culture.

Leitch (1983:59) asserts that the text is not an autonomous or unified object, but a set of relations with other texts. Its systems of language, its grammar, and its lexicon, drag with them numerous bits and pieces - traces of history - so that the text resembles a cultural Salvation Army Outlet with an unaccountable collection of incompatible ideas, beliefs and sources.

Intertextuality is a broad concept that includes, among other things, a fluid relationship that exists between the author and the text, the text and the text, and lastly the reader and the text. The term also includes a relationship, where a text alludes to or redeploys an entire structure, a pattern of form and meaning from a prior text as well as what may be termed simple allusion, i.e. where a text repeats an element from a prior text without using its meaning. This article will only concentrate on simple allusion. It will also demonstrate the relationship of parasite/host and host/parasite from selected Setswana poems.

According to Miller (in Bloom, 1979: 225) any poem is parasitical in its turn on earlier poems, or it contains earlier poems within itself as enclosed parasites, in another version of perpetual reversal of parasite and host. According to Miller, the previous text is both the ground of the new one and something the new one must annihilate by incorporating it.

There is a link between earlier and more recent poems that forms a chain. For example, Setswana modern poetry has a link with Setswana indigenous poetry. The traditional Setswana poetry was recited, not written. As a result, it contained many repetitions to allow the listener to follow what the poem was about and to understand the contents. Earlier written poems in Setswana had the same technique, device or analogy. Each link in the chain, in turn, played a role as host and parasite in relation to its predecessors - from a bard making recitals to Raditladi, Lekgetho, Mafonyane, Moroke, Molefe, Legodi, Chweneemang, Motlhake, Montsho and Mothoagae writing poetry.

Another important aspect of intertextuality is that writers also use other images from sources such as the Christian faith, world-views and African traditional beliefs. This article will focus on the traditional beliefs of the Batswana, as reflected by an intertextual analysis of Mothoagae's poetry. The article will also use Miller's analogy of parasite/ host and host/parasite, a reciprocal relationship between texts.

\section{The traditional beliefs of the Batswana}

Like all other nations, the Batswana have their own beliefs. Only a few of these beliefs will be dealt with in this paper: witchcraft, ancestral world, customary marriage, mythology and intertribal emulation. 


\section{Witchcraft}

The Batswana believe strongly in witchcraft (boloi). Boloi is sometimes practised singly, but more commonly in groups. Old women are often suspects. Since the culprit is a mother or grandmother of a living member of the community, even the traditional doctor, who identifies her, does not reveal her name for fear of disrupting the peace of the community. The main motives of witchcraft are greed, vengeance and envy. The purpose of a witch is to kill or injure a particular person. The injury may be moral in nature. The overall aim of bewitching a person is to reduce his/her worth so that he/she becomes lazy and loses interest in work, or to cause a likeable person to become unpleasant.

The sorcerers are also portrayed as tricksters and doers of harm. They go naked, enter houses through closed doors and windows, and delay the recovery of the sick. They enter the cattle kraal and suck the cows' milk so that the yield is insufficient. They may also suck milk from the nursing mother so that there is insufficient milk for the child. When the moon is full, they gather in groups to dance and play - usually around a tree that is a landmark. They are invisible except to those who have been strengthened with appropriate medicine to see them. The following extract illustrates the extent of this belief.

(1a) Boloi 'Witchcraft'

Dilo di dirwang ka kwa dikhurutsheng

di iketsetswang ke ena Mmampipi.

(Magoleng \& Motlhake, 1969:8)

'Things done at secret places

Done by the witch herself.'

In this poem, Magoleng and Motlhake (1969) describe witchcraft as an issue that is practised secretively. Witches go about their activities at night, when they cannot be seen by anyone, and enter the homes of people to bewitch them. The poet suggests that witchcraft shows that people are less significant than ants. Ants perform their tasks with great effort; witches are lazy, and they bewitch people who have progressed in life. Magoleng and Motlhake (1969) opine that the black community will not benefit from witchcraft. Witchcraft will enslave blacks for their entire lives. It will deprive them of all that belongs to them. The poet appeals to God to intervene and stop the witches from practising witchcraft, as this alone can convert witches to become Christians.

Magoleng and Motlhake (1969) refer to the real deeds done by witches. They say that witches are cowards because they do not want to be seen. They conduct their operations in hiding because they are not brave enough to be seen. They do not take responsibility and accountability for their actions. Magoleng and Motlhake (1969), as host writers, use witchcraft in a literal sense. Compare Magoleng and Motlhake (1a) above with Mothoagae ( $1 \mathrm{~b})$ below:

\section{(1b) Lefif 'Darkness'}

Kobo e ntsho kaparwa ke bommampipi baloi

Tiro di dirwang go wena di sisimosa mmele.

(Mothoagae, 1989:63)

'The black blanket dress of secret witches

Deeds done in the dark (in you) give one the creeps.'

Mothoagae in ( $\mathrm{lb}$ ) explains how the darkness of night serves as a cover for witches and criminals. Witches and criminals take refuge in the dark so that they cannot be noticed by anyone during the course of their activities. The poet describes these activities as dreadful. Activities that are carried out in the dark, tend to be sorrowful. People who meet during the night are confidence tricksters. The devil himself is fond of darkness. The poet appeals to the sun to rise quickly. Darkness fears sunlight; they are hardly seen together. The poet explains that if he knew how to practise muti (medicinal charms), he would bewitch darkness to get rid of it so that mankind could live peacefully. 
In Setswana, witchcraft is associated with darkness and vice-versa. Witchcraft is an evil practice that is used to hurt people. Mostly, witches are poor people who struggle to make ends meet. As a result, they become bitter and frustrated. Out of rage borne from envy, they try to bring successful people to their knees. They do not want to be recognized because people will hate and isolate them; hence everything is done in secret.

Magoleng and Motlhake's (1969) description of witchcraft is clarified by Mothoagae, the parasite, who uses the term 'witchcraft' in a figurative way. Mothoagae describes darkness as a blanket worn by witches. This means that evil things happen during the night. Evil things, in this regard, may not necessarily mean actual witchcraft but may include other crimes such as murder, theft, burglary and rape, because they are also done in the dark.

Witchcraft, which is understood to be of no value because of its covert and hidden operations, becomes clearer in Mothoagae's text. In this way, a reciprocal relationship exists between the two texts. Witchcraft is again embedded in images evoked by these lines.

(2a) Moloi 'A witch'

Tshwara tshipi, nkono, re ye kgakala

Re palame poka re ye go batlhola.

(Molefe, 1964:7)

'Catch a plane, grandmother, let's go far away

Let's ride the dew and pay them a visit.'

Molefe's (1964) poem (2a) above is an overview of witchcraft, which the poet says is prevalent in society as it is practised by almost all people regardless of their status in the community. Witchcraft is a night time activity that people learn in their homes, and it is commonplace among both the rich and the poor. The poet declares that witches regard their activities as both harmless and recreational, even though they may not like to be seen while carrying them out. The issue of witchcraft, of which one of its main activities includes a shoe- or broom-bound flight, is traditionally viewed by both its perpetrators and the community as a tight-lipped secret. The poet asserts that the primary aim of witches is not to persecute their victims, but to discipline them.

(2b) Kgaje-a-Makibisi 'Kgaje son of Makibisi'

$O$ senatla o thata o palama foleimatshine,

O palama nonyane e tala tladi a goletsegele marung.

(Mothoagae, 1989:1)

'You are brave - you are strong - you ride an aeroplane

You ride a bird of lightning and are wanton in the air.'

The above extracts indicate that the -witches have a mode of transport to facilitate their 'business'. As can be expected, this mode is unusual because it must not be seen or used by other people. Witches cannot use ordinary transport because they do not want to be seen and they really need the most convenient and reliable means of conveyance. They have invented their own transport to suit their particular needs.

It is believed that witches use a traditional broom to carry out evil deeds in far-away places. It is also believed that, in most cases, witches are elderly people, especially women, hence nkono which means grandmother. Their business is conducted during the night, when dew falls. Their aeroplane tshipi is driven by the wind, which is damp because of the dew, hence Re palame poka.

If one considers the host, Molefe (1964) in (2a), one observes that the poet has introduced the mode of transport used by the witches at night, whereas Mothoagae (1989) (2b), as the parasite, borrowed this idea from Molefe (1964). Mothoagae (1989) goes on to clarify this image by exposing the fact that not everybody can ride this plane, only the brave. Molefe's (1964) text becomes the parasite by gaining more clarity from Mothoagae, who becomes the host. 


\section{Ancestral world}

At death, all initiated Batswana become badimo (ancestors). Babies are a gift from badimo. The ancestors are regarded as the agents of God. The function of the ancestors is to ensure a good order of social relationships among the biologically living, and the fertility and well-being of men, their crops and stocks. In return, they expect service. Their attitude to the living is basically parental, protective and corrective, and aimed at the welfare of the whole group. According to Setiloane (1976:65) the ancestors:

...continued to take active interest in the fortunes of their living descendants, over whose behaviour they exercised a powerful control. They rewarded with good health and prosperity those who treated them with becoming respect and obedience, but punished with sickness, economic loss, or some other misfortune, those who neglected them or who offended against the prevailing code, of which they were the guardians.

The ancestral worship of Africans, in general, is based on the belief that the living and the dead can mutually influence one another. This influence that the living has on the ancestral spirits forms the basis of all rites connected with the ancestral spirits. The importance of ancestors in African life is better described by Kuckertz (1983:114):

Another reason for the ancestors' universal significance is that they are a means of interpreting certain negative events which occur in a person's life.

There is a relationship between Mothoagae's works and those of other Setswana authors concerning the ancestral world. Compare Lekgetho, Kitchen and Kitchen (1949:38) in (3a) and Mothoagae (1990:22) in (3b).

\section{(3a) Kgosi Robanyane Toto II 'Chief Robanyane Toto II'}

O epolotse marapo a baswi re bua nabo.

(Lekgetho et al., 1949:38)

'He has exhumed bones of the dead we talk to them.'

Herein the poet gives an account of the restoration of the Bahurutshe chieftainship that was forcefully taken from the tribe by the erstwhile apartheid government. The tribe was filled with joy when their rightful Chief Robanyane Toto was installed to lead the Bahurutshe. According to the poet, the restoration of the chieftainship symbolizes the joyful moment of the previously disaffected ancestors of the Bahurutshe tribe. This joyous occasion also implies the restoration of the tribe's traditional dignity and signifies the apartheid government's defeat in its bid to dispossess the Bahurutshe of their rightful chieftainship. Chief Robanyane, in line with the tribe's traditional beliefs and customs, invites his relatives and his co-chiefs as well as neighbouring communities to celebrate this historic moment with the Bahurutshe.

The poet highlights the conditions of the Goo-Mothware chieftainship, which was dissolved through orders from the former white government. Upon the restoration of the chieftainship by the white government, the poet remarks, 'the installation of Chief Robanyane Toto II symbolizes the restoration of the Goo-Motlhware chieftainship.' The idiomatic expression that 'we are communicating with the dead because he has exhumed their bones' infers that 'the dissolution of the Goo-Motlhware chieftainship has sparked an outcry from Chief Robanyane Toto II's ancestors, who died many years ago, because the sovereignty of their territory together with its subjects have been subjugated by a foreign white government.' Chief Robanyane Toto II's ancestors are ululating now that the heir apparent has been restored to his rightful chieftainship.

(3b) Keledi tsa Motlhotlho 'Tears of Sorrow'

Badimo ba rona re rapeleleng kwa go lowe.

(Mothoagae, 1990:22)

'Our spirits give our prayers to our forefather.' 
The poet makes an impassioned plea to his ancestors to come to the rescue of his nation following its abuse of liquor. The poet's heart is seething with pain at the high degree and indiscriminate way in which the youthful community is consuming liquor, plunging their lives deeper into a bleak future. 'Now that the youths, who are the pillars of our future society, are abusing liquor, who will be responsible for the birth and upbringing of children?' he asks, as he internalizes the problem. With his plea having fallen on deaf ears, he hopes the ancestors are able to intervene with efficacy.

The Batswana believe in the existence of ancestral spirits. The tribe must always be in close contact with these spirits and sacrificial ceremonies are conducted to appease them. When the tribe is riding on the wave of prosperity, it is believed that the ancestors are happy. When the spirits are happy, they shower the tribe with good fortune, but when they are angry, they punish the tribe through supernatural sanctions. Witchcraft is considered as a wrong of the highest order and is legally punishable by death. Lekgetho et al.'s (1949:38) extract in (3a) suggests that the ancestors have been angry for a long time, but have now decided to let sleeping dogs lie. 'He has exhumed the bones of the dead ....' This suggests that the communication channels were closed. The tribe was unable to communicate with their ancestors. It was a painful experience; hence, with a sigh of relief, '.. we talk to them'. The problems are now a thing of the past.

Mothoagae's phrase (1990:22) in (3b) complements the phrase of Lekgetho et al. (1949:38). Mothoagae (1990) seeks to avoid confrontation with the ancestral spirits. He is thus taking a pre-emptive step by 'asking our ancestors to pray for us'. It also means that the ancestors must forgive us our trespasses. Mothoagae's (1990) phrase provides answers and suggests that people should not repeat the mistakes of the past.

The ancestral world is also portrayed by the following lines; compare Seboni (1958:19) in (4a) and Mothoagae $(1990: 10)$ in (4b):

(4a) Leboko la dikgomo 'Ode to cattle'

Ka e se dikgomo e le ditsosabadimo.

(Seboni, 1958:19)

'For they are not oxen but ditsosabadimo.'

(4b) Khuduga 'Emigration'

Mafoko a khuduga ga se mafoko ditsosabadimo.

(Mothoagae, 1990:10)

'News of emigration is not news but ditsosabadimo'.

The poem in (4b) depicts the migration of the Bahurutshe tribe from their traditional land, which they treasured very much, to a new area. The tribe, used to the good and evils of their land, was initially opposed to the migration. Nevertheless, when the members realized that the soil of their land could cause them problems in the future, they had to accept the circumstances that necessitated the migration. The tribe became anxious that the migration could have far-reaching implications for their ancestors. The ancestors could move from their resting place, as the migration would leave them with no one to look after them, and the Bahurutshe would be deprived of their shepherds at their new location. Both the tribe and their ancestors were equally concerned at the separation caused by the migration.

The ancestors demonstrate their emotions and feelings through actions. The Batswana have a saying Badimo ba eme ka dinao, (translated literally as 'Spirits standing on their feet') meaning that the spirits are angry and need to be appeased. The tribe strives to keep the ancestors happy because it is for their own good. 
Seboni (1958), in his poem (4a), refers to oxen as ditsosabadimo meaning that when they low they are inviting the spirits to join the living. People spend sleepless nights thinking about their oxen. Those who possess many oxen are afraid that they will be stolen, and those who have no oxen, yearn to possess some. Different tribes, groups or even nations have fought fiercely to dispossess those who own them. However, the ancestors would come to life if there was no peace and serenity. Clearly, Mothoagae (1990:10) extends the meaning of ditsosabadimo to mean vexatious and agitative. Even though he has taken this concept from Seboni (1958), the meaning of the concept becomes more vivid in his hands. Seboni's (1958) text, embedded in Mothoagae's (1990:10) text, clearly indicates how the host text can participate in the articulation of various significations through a perpetual reversal of parasite and host.

\section{Customary marriage}

When an initiated boy becomes a man, his parents will inform relevant family members such as the malome (maternal uncle) and rakgadi (paternal aunt) that the young man is ready to get married. In traditional societies, the family used to look for a suitable cousin to marry the young man. According to the Batswana, internal marriages were preferred to external marriages. When a boy married his cousin, it was said dikgomo di boela sakeng meaning that the family's cattle would not be lost to strangers. Another important reason was to protect their children against witchcraft, which was prevalent during those days. To all intents and purposes, the boy did not marry for love as such, but for keeping the family's name alive. The boy did not contribute anything when the lobola (bride price) was paid. The responsibility for the wedding celebrations was shouldered by the family.

Marriage among the Batswana was not an individual affair legalizing the relationship between a man and a woman, but a relationship between two groups of people. The relatives of the groom transferred certain marriage goods to the relatives of the bride. In return, the bride was publicly transferred by her relatives to the in-laws. These marriages formed the nucleus around which the life of the Batswana revolved. Compare Raditladi (1964:14) in (5a) with Mothoagae (1989:24) in (5b).

\section{(5a) Selelo sa Morati 'Lover's lament'}

Mosadi wa me ba se na go mo nneela.

(Raditladi, 1964:14)

'My wife - after she was bestowed to me.'

The poem depicts a poet's love for his co-poet. The poet tells of an incident in which one poet requested and dispatched his family to arrange a marriage for him from the Bakgatla tribe. The arrangements were progressing well, with the families of both the prospective bridegroom and bride having designated a day on which the lobola would be paid. While messengers were en route from the home of the would-be bridegroom to the prospective bride's home to finalize the preparations, the poet's mistress died. While the poet was grieving his mistress' death he declares that, in accordance with the Setswana tradition and customs, it is unlawful for a Motswana man to look for a prospective wife himself and subsequently marry her without the support of his parents i.e. contrary to modern-day practice and in line with Setswana tradition and customs, a Motswana man should have his marriage arranged by his parents. According to the poet, this type of marriage is the basic principle on which Batswana fämilies are founded.

(5b) Maipolelo a lerato 'Lover's confession'

Mosadi ka pelo tshweu lo mo nneile ke a leboga.

(Mothoagae, 1989:24)

'Thank you for heartily handing this woman to me.'

In this poem, the poet lauds his in-laws for the wonderful wife they have bestowed upon him and the Bakwena tribe, in particular, for having chosen a noble wife for him. He also speaks of his happiness that the Bakwena tribe has chosen a beautiful wife for him. The poet concludes his poem by assuring his youthful wife that he would laud her in her future old age. 
In Raditladi's (1964:14) poem (5a), the narrator is thankful and proud that he was given a good wife, but laments her death. The phrase ba se na go mo nneela suggests that she is no longer alive or that she is no longer living with the narrator. The wife in Raditladi's (1964:14) poem was given to the narrator, as was the case in Mothoagae's poem (1989:24) (5b), but in Mothoagae's poem the narrator and his wife are still together.

The manner in which the man and the woman relate is typical of how, within African culture, a husband relates to his wife. The husband is regarded as the provider and the wife as the recipient. The wife is a 'gift' for which the husband must be grateful. The husband must look after his 'gift', care for it and even protect it against any danger. The wife, in turn, will reciprocate by respecting and honouring her husband.

\section{Mythology}

Setswana mythology deals with a variety of subjects, all revolving around man, around whom the created universe is centred. The most outstanding events in human life are birth, marriage and death. Most myths deal with origin, marriage and death. Plottel and Charney (1978:8) observe that the basic function of a myth, as we now generally recognize it:

...is to provide order that conserves and transmits the multiplicity of beliefs, insights, lore, experience, so that the myth is preserved and continues to be of service to the community.

The following poets have drawn their images from Setswana mythology; compare Mokone's (1963:66) poem in (6a) with Mothoagae's poem (1989:45) in (6b).

(6a) Lebodu - Chameleon

Ga twe ere batho go swa, ba swele ruri

Badimo ba amogela mafoko a moselenyane.

(Mokone, 1963:66)

'It is said when people die, they must die eternally.

Ancestors accepted agama's words.'

(6b) Loso 'Death'

A khutsanyana ya go swa kgantlapane

E koo e se wena loso e ka bo e le thobalo.

(Mothoagae, 1989:45)

'Poor orphan that dies agama

Had it not been for you, death would have been sleep.'

In (6b), Mothoagae (1989:45) critiques the cruel conditions that death often leaves in its wake, elaborating that people no longer die in the same circumstances as in the past. Death, according to the poet, deprives people of their loved ones and kills with impunity, turning children into orphans. The poet apportions blame for this state of affairs on a chameleon. Instead of heeding an important message, the chameleon preferred to consume gum. Had the chameleon heeded this important message, mankind would not have had death in its midst.

These quotations are based on a well-known Setswana myth. It is said that once upon a time a chameleon was sent by God to tell the people that human beings should not die entirely, but be brought back to life. It took a long time for the chameleon to reach his destination because of his sluggish movement. A few days after the chameleon's departure agama was summoned. On his arrival, he was commanded to run with all his might to tell the people that human beings must not have the ability to be resurrected. Agama ran as fast as he could, passing the chameleon on the way, and his message was accepted. When the chameleon arrived, the people refused to listen to him. From 
this mythology originated the proverb Mafoko ke a pele, a morago mapepentlwane, meaning first-comers' words are important but those of late-comers are worthless. In both cases, death is the main theme.

Death, in Mokone's text (1963:66) (6a), is caused by agama, the messenger, because he was the first to reach the people with his message. In Mothoagae's (1989:45) text, agama is associated with death. Khutsanyana means an orphan. Agama also lost his parents and he also faces death ya go swa. He will not be able to escape his fate even though he served his masters loyally by taking the message to the people.

The two extracts from Mokone (1963:66) and Mothoagae (1989:45) respectively, seem to complement each other. Having borrowed this idea from Mokone's (1963:66) text, Mothoagae (1989:45) goes even further. He suggests that death plays the role, or has the function of sleep, meaning that human beings need a rest; a break to attain peace of mind.

There is no myth or story in Setswana folklore that explains the creation either of man himself or the world in which he lives. This vacuum may have been created by the belief that, traditionally, the Batswana originated from a place in central Africa known as Ntswanatsatsi ' where the sun rises'. It is believed that they were living in a cave of which the exact geographical location is unknown. The cave was round, and as a consequence, the Batswana's traditional houses are round to this day. In Setswana tradition, it is believed that the first Motswana to arrive in this world was Lowe, but before making his way out of the cave, he sent his trusted servant Matsieng to see what the place looked like. Matsieng returned to the cave after inspecting the territory and gave his master a good report about what he had seen. Lowe came out of the hole to start a nation of Batswana people. He had one eye, one leg and one hand that symbolized unity and oneness. The following extracts will confirm this belief; compare (7a) and (7b).

\section{(7a) Phokokgolo 'Big Scandal'}

Batswana ba ga Lowe matlhale.

(Legodi, 1986:7)

'Lowe's descendants are wise.'

The poet illustrates the significance of the Setswana traditional beliefs and customs which forbade the Batswana of Lowe to discuss scandals. Modern-day life is marked by infighting due to the Batswana's lack of knowledge about their proverbs. The Batswana are unaware that scandals may not be discussed publicly, as they are a risk factor in causing infighting among people and dividing families.

Legodi (1986) suggests that people, who divide families and cause infighting among others by discussing scandals publicly, should be punished. This often happens when two people exchange confidences to seek each other's advice and one of the two discloses the matter to others despite being told not to. By revealing the secret to others, he/ she would not only have demeaned a Setswana custom, but would also have betrayed the trust of his/her friend.

The poem pertains to a proverb of the Batswana nation that suggests that the Batswana have traditionally desisted from being a source of any information that is connected to scandals or news of any kind that could negatively implicate its source. The poem pays tribute to the Batswana of yesteryear for their wisdom and foresight. They have laid a solid foundation on which the present generation can tread with pride. Reference is made to Lowe, their founder. As the first Motswana to come to earth, he set the standards to be followed by his descendants. The proverb, from which the title derives, carries a universal truth.

(7b) Metholodika 'Ominous Happenings'

Ratla ja yone ja kutumolola Lowe badimong.

(Mothoagae, 1990:27)

'The loud sound exhumed Lowe from the caves.' 
Mothoagae (1990:27) paints the gloomy picture of happenings when the erstwhile Bophuthatswana government was violently toppled by its opponents prior to post-apartheid South Africa. He tells of the mayhem that reigned during the bloody takeover in that former nominally independent homeland, and how the gunfire during the armed invasion into the beleaguered state could even exhume Lowe from the grave.

As is evident from the above, both poets have used the image of mythology. Legodi (1986:7), in (7a), conveys that his life as a Motswana has links with Lowe (supposedly his great-grandfather) and that all the Batswana inherited their wisdom from Lowe. In Mothoagae's poem (1990:27) (7b), the respect that is attached to Lowe is extended. Mothoagae (1990) opines that for all the good deeds the Batswana inherited, they should at least show their appreciation by being silent and peaceful.

\section{Intertribal emulation}

In most cases, the striving after tribal cohesion clashes with the striving after splintering. When the tribe was in trouble, cooperation and solidarity became evident. When a member of the community is looking for shelter and security he/she often says:

(8a) Rakgobe 'Father of Kgobe'

Taukometsa oora Mmenyane

Se reng Taukometsa loa mo gakatsa.

(Lekgetho et al., 1949:70)

'The lion swallower of Mmenyane

Don't say - lion swallower - you provoke him.'

Likewise he/she may say:

(8b) Tautona ya Marekwa 'Leader of Marekwa'

Ya duma gangwe ka kodukgolo Tau ya Marekwa.

(Mothoagae, 1990:13)

'The lion of Marekwa roared once with a loud voice.'

The poet advises the leader to be loyal to his people. He must not accept bribes, as this will taint his name. He must protect his subjects against enemies.

It is clear that both narrators compare their leaders to a lion; the fearsome lion is known for its courage and strength. In Lekgetho et al.'s (1949:70) poem (8a), the narrator, who is also a member of the community, expects his leader to show these qualities during trying times. The first phrase suggests that the leader is going to swallow the enemy. The leader, who is a chief or a king, will be flattered by this and do everything in his power to maintain his dignity among his people. Mothoagae's (1990:13) extract in (8b) is also praiseworthy. In Mothoagae's (1990:13) extract, the narrator is urging the leader to scare the enemy by making a loud sound. If the enemy does not want to be swallowed, they must avoid confrontation; they must avoid the roaring sound at all costs. Mothoagae's (1990:13) text therefore seems to complement Lekgetho et al.'s (1949) text.

Intertribal emulation also occurs in the following poems; compare (9a) and (9b).

(9a) Ba Malete 'Malete tribe'

Di robaroba matlhakola

Di a robarobile fela di sa tla go a lala.

(Seboni, 1958:26) 
'Gatherer of the bush berries

They have gathered it but they are still going to lie upon it.'

In (9a), Seboni (1958:26) describes the Ba Malete tribe, their conduct and behaviour, as well as their distinctive culture that has manifested itself into a tribe. The tribe lives in an area that is inhabited by matlhakola (bush berries). The poet is of the opinion that the tribe is not tactical in its approach to life. For them, the present is more important than the future. For example, they can spend time collecting matlhakola only to lie on them with the hope that the following day they will get more matlhakola. If you wage war against the tribe, you must know what you are up against. The Ba Malete are not an easy prey and they never surrender; if you are their enemy, they are as fearsome as a buffalo. When you think about them, climb the nearest thorn tree as quickly as you can.

This is a praise poem of the Malete tribe of Botswana, near Gaborone. They are excellent military tacticians who easily encircle their enemy by using a crescent formation, are capable of great deeds of bravery, can be engaged in the dangers of warfare, and are the finest offspring of Mapula.

(9b) Mokopi-a-kgang-a-Senosi 'Daughter of Kgang of the Senosi Clan'

A ga robaroba let lhakola

A le roba fela a sa ye go le ala.

(Mothoagae, 1989:16)

'Gatherer of the bush berries

Gathering it but not going to lie on it.'

Mothoagae (1989) describes Mokopi as a beautiful light-complexioned lady and a daughter of Kgang and Kebadiloe. The poet lauds Mokopi for being a steadfast woman who looks after her homestead, and for her leadership qualities. He speaks highly of her good deeds that include the raising of her children, and being a role model of good conduct who enjoys the same respect as is accorded to the elders. As a daughter from the royal line of Phefo and Senosi, she is destined to become a queen.

Mothoagae (1989) borrows his tools from Seboni and Lekhela (1978) to describe Mokopi. After reading Mothoagae's (1989) text, one sees the qualities of Mokopi's forebears, Masodi and Mphela (Ba Malete), in her character. The Ba Malete is a very brave tribe although its bravery sometimes exposes it to danger. For example, when the tribe was once attacked without notice, its members were expected to flee from the enemy, but because of their stubbornness, they decided to fight their enemy, as ill-prepared as they were. As a result, they lost the battle and most of them were killed.

Mothoagae (1989) borrows the image, but he uses this image differently. Mokopi gathers bush berries so that she can feed her children; she would like her children to grow strong. She is also a stern, but tactful, disciplinarian. As a future queen, she needs the qualities of the Ba Malete to fight back enemies. In Mothoagae's text, no one lies on the bush berries after gathering them. By extending the image he borrowed from Seboni and Lekhela (1978), Mothoagae (1989) turns Seboni and Lekhela's (1978) text, which was initially the host, into the parasite.

The following poems also describe intertribal emulation; compare (10a) and (10b).

(10a) Barolong 'Barolong tribe'

Namane tsa tholo, Barolong

Di jang mogope di o lala.

(Seboni, 1958:28)

'Kudu's calves, Barolong

Eating a hut in which they lie.' 
Seboni (1958) praises the solidarity that the Barolong tribe displays when they perform their tasks. He says the tribe is a close-knit community. Members of the tribe work jointly and help one another. The Barolong have a gift for manufacturing tools with iron. The tribe's customary name is Baga Morara a Noto, which it owes to its first early leader who had a gift of iron-smelting prowess that he utilized in manufacturing cooking pots, knives and axes, as well as other utensils.

(10b) Mmabatho 'City of Mmabatho'

Mafika a Barolong boo Tshidi Barolong

Namane tsa tholo Barolong di jang

mogope di o lala.

(Mothoagae, 1989:36)

'Rocks of Barolong of Tshidi Barolong

Kudu's calves Barolong eating a hut

in which they lie.'

Mothoagae (1989) lauds Mmabatho, the capital of the former Bophuthatswana homeland. He compares the capital to a beautiful woman and further explains that Mmabatho is like the mother of people, as the capital has placed all children in its custody without discrimination. Mmabatho is inhabited by people of diverse cultures and abounds with everything. The capital boasts schools, shops, courts of law, sports fields and a cultural village. Illegitimate children have even forgotten about their tribulations. Masiela and orphans live in comfort. Nobody begrudges Mmabatho her success.

The two extracts have been quoted from the praise name of the Barolong, a Setswana tribe. The original praise composition shows the courage displayed by the tribe. Yet, in spite of their good qualities of being military experts, they sometimes act as fools by 'eating' their own hut, i.e. exposing themselves to danger. Seboni (1958) described only the characteristics of this tribe, while Mothoagae (1989) extended the depth of meaning, by even describing their place of abode. This Batswana tribe is situated in Mafikeng, in the North Western province.

This comparison evokes memories of Raditladi's (1964) poem, Aferika, in which he also compares Aferika with an attractive woman. The following extract shows striking similarities with Mothoagae's Mmabatho:

Lefatshe le ke mosetsana.

'This land is a lass.'

The central tenor and vehicle relationship between land and girl depends strongly on the shared quality of beauty. There is a Setswana proverb that qualifies the notion of beauty as follows: Bontle bo na le dibelebejane bo sa loeng bo a rota. Translations or paraphrases of this include: 'Beauty has in it good and bad; beauty is the source of conflict and reconciliation; beauty, if it does not bewitch, it heals.' It is the author's perception that the intertextual relationship between this proverb and the text of this poem, in the form of an allusion, relies not so much on the presence of the word 'beauty' in the poem Aferika, or on the way this element is associated with the tenor, land, and the vehicle, girl, in terms of the various facets of their shared beauty, but rather on the strong phonic parallelism that draws the proverb into the sound-meaning relationship that is so strongly communicative in the second stanza. The patterns of sound repetition provide a strong intertextual connection which qualifies the two opposing facets of the notion of beauty in terms of the proverb. This allows for a reading of the central metaphor itself in terms of this proverb, upon which much of the productive ambiguity of the metaphorical relationship relies. The girl is good looking, hence compare (11a), (11b), (11c) and (11d) with (11e) and (11f): 
(11a) Mothoagae (1990)

Makolwane a boka bontle jwa gagwe phetelela.

'She is immensely admired by gentlemen.'

(11b) Raditladi (1964)

Moratwa [w] a[di]thaka tse dikgolo.

'One cherished by eminent guys.'

(11c) Mothoagae (1990)

Bothakga jwa Motswana ngwana wa sebilo.

'The beauty of a dark-skinned Motswana girl.'

(11d) Raditladi (1964)

Ntswa fela a le mmala motshwana,

'Although she is dark-skinned,'

(11e) Kgamanyane Pilane 'Chief Kgamanyane Pilane'

Ke lemawana le nthapedi

Le thabelang kobo le moroki tshekedi

Ke re ke le kwano ke koo

Ntlha nngwe ke tswele borokgwe, ntlha nngwe lekebi.

(Schapera, 1953:70)

'I am the awl with two points

Which pricks both the hide and the mender

While I am this end, I am that end

One leg wearing a trouser and the other a loin skin.'

In (11e), the poet speaks of Chief Kgamanyane Pilane, describing him as a cunning person who often converses with the British authorities with the aim of soliciting secrets from them that would enable him to launch attacks on them.

(11f) Marara a botshelo 'Life's complications'

Mao lwa ntlhapedi lo thabang moroki

le serokwa botlhoko.

(Mothoagae, 1990:2)

'An awl with two points which pricks the sewer and the sewn painfully.'

The poet gives a graphic description of life today as being riddled with complications, saying that life's issues are not really as they appear to be on the surface. Life issues are actually deep-seated mysteries, which are difficult to unravel. People whom you trust and with whom you come into daily contact are actually the ones who are likely to take your life unawares. Because of their close contact with you, they keep themselves abreast of your whereabouts, and you are likely to be caught napping when they mysteriously attack. Your would-be murderer keeps smiling at you while he hatches a plot to kill you.

Lemao la ntlhapedi is a metaphor used for a devious person. In the first phrase, Kgamanyane Pilane is described as a person with divided loyalties. Kgamanyane Pilane was leader of the Bakgatla tribe at Mochudi in Botswana. He reigned during difficult times, (1848-1874), when white supremacy was the order of the day. He had to be 
loyal to the British authorities, whose interests clashed with those of his tribe. He was torn between the dominant white race and his fellow blacks. The whites in the Transvaal employed the Bakgatla as auxiliaries in their war with other native tribes. They also required Kgamanyane Pilane to furnish people to work on their farms. In 1869 he refused to comply with one such request and was publicly thrashed by the whites in front of his people. Another incident occurred in 1858 when war broke out between the Boers and the Basotho (of Lesotho). Like several other Transvaal tribes, the Bakgatla were enlisted as auxiliaries. This created a conflict of loyalties for Kgamanyane once more, as he was a son-in-law of the famous Chief Moshweshwe.

Mothoagae, (1990) in his poem Marara a botshelo, may have borrowed the extract from Schapera's (1953) text. Mothoagae's text has extended the meaning of mao lwa ntlhapedi to address an area that is not covered by Schapera's (1953) text. Mothoagae uses mao lwa ntlhapedi to describe hypocrisy. He suggests that a person may appear to be friendly while he is not. What he means is that we must never trust our best friends because, at times, they can be our worst enemies.

\section{Conclusion}

The aim of this article was to demonstrate the relationship between some Setswana poems through an intertextual analysis and to determine the relationship between the written texts and cultural practices of the Batswana.

This article has shown that Batswana writers borrow images, phrases, words, metaphors and experiences from one another and it is evident that writers of recent publications borrowed images from earlier publications. This is not surprising, because every writer has read books by other writers before writing their own books. Hence there is a saying that there is no originality, i.e. origin of origins. Every writer is born into a community. He experiences life within that community. He reads books and views pictures and paintings that shape his thinking and his way of life.

This article used Miller's (in Bloom, 1979) theory of host/parasite and parasite/host relationship. This means that there is a mutual relationship between the texts. The parasite text borrows the image from the host text and the image borrowed from the host text gains more meaning and clarity from the parasite text. The host text may have borrowed its image from another earlier text that came before it or from the cultural setting. Morgan (1985:8) emphasizes that:

Indeed culture itself or [a] collection of signifying practices in a society serves as [a] good source for writers. Culture itself is radically intertextual.

As has been indicated, the images in the article relate to the cultural practices of the Batswana. Intertextuality emphasizes the interrelationship between texts and culture, i.e. for any reader to understand the meaning of the text; he must understand the cultural background of the language.

\section{References}

Bloom, H. 1979. Deconstruction and criticism. New York: Continuum.

Culler, J. 1981. The pursuit of signs: Semiotic literature, deconstruction. London: Routledge and Kegan Paul.

Kuckertz, H. 1983. Symbol and authority in Mpondo ancestor religion in African studies. Johannesburg: Wits University Press.

Kunene, D.P. 1970. Research into the vernacular literatures of Africa south of the Sahara. Research in African Literatures 1(2):157-162.

Legodi, J.K. 1986. Sebribe Maloba. Mmabatho: Maikatlapelo Publishers.

Leitch, V.B. 1983. Deconstructive criticism: an advanced introduction. New York: Columbia University Press. Lekgetho, J.M., Kitchen, M.S. \& Kitchen, N.H. 1949. Boswa jwa puo. Cape Town: National Book Printers. 
Lenake, J.M. 1984. Poetry of K.E. Ntsane. Pretoria: J.L. van Schaik.

Magoleng, B.D. \& Motlhake, S.F. 1969. Maboko a Setswana. Pretoria: J.L. van Schaik.

Matjila, D.S. 1995. An intertextual analysis of D.M. Mothoagae's poetry. Unpublished MA dissertation. Potchefstroom: University of Potchefstroom.

Milubi, N.A. 1988. Some aspects of Venda poetry. Unpublished doctoral thesis. Pretoria: Unisa.

Mokone, N.G. 1963. Montsamaisa bosigo wa bothano. Johannesburg: Juta \& Co. Ltd.

Molefe, R.D. 1964. Mesomo. Johannesburg: Bona Press Limited.

Moleleki, A.M. 1988. A study of some aspects of K.P.D. Maphalla's poetry. Unpublished MA dissertation. Pietersburg: University of the North.

Moloto, E.S. 1969. The growth and tendencies of Tswana poetry. Unpublished doctoral thesis. Pretoria: Unisa.

Morgan, T.E. 1985. Is there an intertext in this text? Literary and interdisciplinary approaches to intertextuality. American Journal of Semiotics 3(4):1-40.

Mothoagae, D.M. 1989. Kgodu e e tswang lerotseng. Mabopane: L.Z. Sikwane Publishers.

Mothoagae, D.M. 1990. Di ole Makgolela. Mabopane: L.Z. Sikwane Publishers.

Ntuli, D.B.Z. 1984. Poetry of D.B. Vilakazi. Unpublished doctoral thesis. Pretoria: Unisa.

Peck, J. \& Coyle, M. 1984. Literary terms and criticism. London: Macmillan.

Plottel, J.P. \& Charney, H. 1978. Intertextuality: new perspectives in criticism. New York: Literary Forum.

Raditladi, L.D. 1964. Sefalana sa Menate. Johannesburg: Educum Publishers.

Schapera, I. (ed). 1953. The Tswana ethnographic survey of South Africa, Part III. Daryll Forde: International Africa Institute.

Seboni, M.O.M. 1958. Maboko maloba le maabane. Johannesburg: Via Afrika.

Seboni, M.O.M. \& Lekhela, E.P. 1978. Boka Sentle. Johannesburg: Via Afrika.

Setiloane, G.M. 1976. The image of God among the Sotho-Tswana. Rotterdam: A.A. Balkema.

Van Zyl, H.J. 1941. Praises in Northern Sotho. Bantu Studies 15(2):119-156.

Vilakazi, B.W. 1938. Conception and development of poetry in Zulu. Bantu Studies 12:16-38. 
Copyright of South African Journal of African Languages is the property of University of Port Elizabeth, Department of African Languages and its content may not be copied or emailed to multiple sites or posted to a listserv without the copyright holder's express written permission. However, users may print, download, or email articles for individual use. 